\title{
An investigation into the cause of road failure along Sagamu-Papalanto highway southwestern Nigeria
}

\author{
Ubido Oyem Emmanuel*, Igwe Ogbonnaya and Ukah Bernadette Uche
}

\begin{abstract}
Investigation into the cause of road failure has been carried out along a $60 \mathrm{~km}$ long Sagamu -Papalanto highway southwestern Nigeria. Geochemical, mineralogical, geotechnical and geophysical analyses were conducted to evaluate the cause of failure along the study area. The results of the laboratory tests showed that the percentage amount of fines ranges from 12 to $61.3 \%$, natural moisture content from 6.8 to $19.7 \%$, liquid limit in the range of 25.1-52.2\%, linear shrinkage between 3.96 to $12.71 \%$, plastic limit ranges from $18.2-35 \%$, plasticity index ranges from 5.2 to $24.6 \%$, free swell in the range from $5.17-43.9 \%$, maximum dry density ranges from $1.51-1.74 \mathrm{~g} / \mathrm{cm}^{3}$, specific gravity ranges from 2.52-2.64 and CBR between 3 and 12\%. The Cone Penetrometer Test (CPT) shows a resistance value of $20-138 \mathrm{kgf} / \mathrm{cm}^{2}$. The major clay mineral that is predominant in the studied soil is kaolinite. The major oxides present are $\mathrm{SiO}_{2}, \mathrm{Al}_{2} \mathrm{O}_{3}, \mathrm{Fe}_{2} \mathrm{O}_{3}, \mathrm{~K} 2 \mathrm{O}, \mathrm{Na}_{2} \mathrm{O}, \mathrm{MgO}$ and $\mathrm{CaO}$. The result of the $2 \mathrm{D}$ Electrical Resistivity Imaging revealed a low resistivity values for profile 2 and 3 ranging from $100 \Omega m-300 \Omega m$, between a distance of $20 \mathrm{~m}-240 \mathrm{~m}$ along the profile to a depth of $7.60 \mathrm{~m}$ and a low resistivity value ranging from $50 \Omega \mathrm{m}-111 \Omega \mathrm{m}$, between a distance of $80 \mathrm{~m}-120 \mathrm{~m}$ along the profile to a depth of $15 \mathrm{~m}$. It was concluded that the low CBR, low MDD and the class of subsoils namely A-26, A-7, A-2-7 (clayey soils) which were identified are responsible for the cause of failure experienced in the study area. These makes the soils unsuitable as road construction materials and hence, there is need for stabilization during the reconstruction and rehabilitation of the road.
\end{abstract}

Keywords: Disaster, Road, Failure, Soil, Liquid limit, Plastic limit, Geophysical investigation

\section{Introduction}

Road transportation is of paramount importance to every society and country. It dictates the pace of socioeconomic development in any country. It is worthy to note that no economy can thrive where there is no good road. However, roads play an important role to the increase of any country gross domestic product. There is a positive correlation that exist between a country's economic growth and the standard of its road network. A country roads network should be designed and constructed in a systematic manner that the intended social

\footnotetext{
* Correspondence: oyememmanuel@yahoo.com

Faculty of Physical Sciences, Department of Geology, University of Nigeria, Nsukka Enugu state, Nsukka, Nigeria
}

\section{Springer Open}

cultural and the economic benefits can be maximized (Ighodalo 2009).

It is of importance to highlight that Nigeria roads have often being characterized with long cracks, potholes and other pavement defects. These has posed a serious challenge and disaster such that in Nigeria one can hardly travel a kilometer without coming across a long cracks and potholes. These has resulted to a spike in the number of road accidents and a plunge on the nation's economic development. Every single road built are often known to have a stipulated design life; but roads often times fail long before the planned expected date; some fail after construction, some after flooding while others last to its entire life expectancy with appropriate maintenance. 
Highway pavements and foundation soils are inseparable duo toward the development of any country (Meshida 2006; Olofinyo et al. 2019). Diverse road failure components are observable within a short period of time after commissioning. Roads are literally constructed on geologic materials and these materials' properties impact their functioning as transport medium (Gupta and Gupta 2003; Olofinyo et al. 2019). The major components of several typical flexible highway pavements from the base to the top include the subgrade, sub-base, base course and riding surfaces (Gupta and Gupta 2003; Adeyemi 2013). However, loss of lives and properties has been linked to the poor design and substandard construction activities arising from non- compliance with the recommended standards. However, road failures are usually followed by the following signs such as rutting, potholes, differential heave, deformation, peeling and cracking (Gidigasu 1976; Alexander and Maxwell 1996). Several factors have been linked to the increasing recorded road failures include geomorphological, geological and geotechnical factors, design and construction inadequacies, maintenances and road usage (Oke et al. 2009; Nwankwoala et al. 2014). Climatic factors in particular temperature alterations and attacks by acid rain have been reported to reduce the performance of the road base materials. Gidigasu (1983) and Graham and Shields (1984) reported insufficient width and the makeup of the road shoulders as other contributing factors that give rise to road failure. Specifically, several pavement failures in the Southern region and Niger Delta region of Nigeria have been traced to hydrogeological and geological conditions linked with swampy, textural properties of the subsoils and poor drainage measures (Jegede 1997; Abam et al. 2005). The prevalence of pavement failures has also been attributed to the engineering characteristics of the underlying geology and the subgrade materials. The engineering characteristics of the underlying geology have been reported to have been controlled by their mineralogical compositions (Akpan 2005; Amadi et al. 2012). Poor geotechnical characteristics of the soils such as poor bearing capacity, low maximum dry density, high liquid limit, plasticity index, optimum moisture content, California bearing ratio and high compressibility are typically responsible for road failures (Akpan 2005; Ademilua 2018). These states often result to pavement failures in the shape of cracked pavements and surface deformation. However, the appropriateness of soils as base course or subbase course and the subgrade are in cogent connection to the conveyance and bearing of axle load which determine the strength, durability and life of roads (Jegede and Olaleye 2013; Nwankwoala and Amadi 2013). Geotechnical assessment of subsoils helps in comprehending the behaviour of the soils that can cause remarkable impairment to road construction and also propose solutions in problems connected with both expansive and unexpansive soils (Daramola et al. 2015; Amadi et al. 2015). Past investigations have also emphasized the role of geophysical investigations and integrated geotechnical and geophysical investigations in the investigation of the significant factors responsible for ceaseless highway pavement failures in parts of southern Nigeria (Salami et al. 2012; Adeyemi 2013).

Sagamu-Papalanto highway is one of the busiest highways in southwestern Nigeria. This is as a result of the presence of some notable industries in the area. The road under investigation is an access route to the Lafarge cement company at Ewekoro, Dangote cement company at Ibese, NNPC gas plant station at Oloruungosho in Ogun state. The bad state of the road has slowed down the pace of socio-economic development and activities in and around the area and its suburbs.

The objective of this study is to determine the engineering geological properties of the soils in the study area using integrated geotechnical and geophysical investigations and their contribution to road failure.

\section{Study area}

The study area lies within Longitude $3^{\circ} 11^{\prime} 35.627^{\prime \prime} \mathrm{E}$ to $3^{\circ} 34^{\prime} 42.25^{\prime \prime} \mathrm{E}$ and Latitude $6^{\circ} 51^{\prime} 1.217^{\prime \prime} \mathrm{N}$ to $6^{\circ} 54^{\prime}$ $16.457^{\prime \prime} \mathrm{N}$ on the $60 \mathrm{~km}$ long Sagamu -Papalanto expressway in Ogun State Southwestern Nigeria (Fig. 1). The area has a wide spread humid tropical climate marked by the alternating wet and dry seasons. The wet season starts in April and ends in October whereas the dry season runs from October to March. The mean annual rainfall is approximately $1375 \mathrm{~mm}$. The mean yearly temperature varies from $22^{\circ} \mathrm{C}$ in wet season mean to $30{ }^{\circ} \mathrm{C}$ in dry season. The humidity ranges from $40 \%$ in December to $80 \%$ in July (Balogun 2003). The study area has moist air that comes from the Atlantic Ocean throughout the year. The relief is moderately, uneven and undulating. The area is predominated by dendritic drainage pattern which implies a quite similar resistance of the underlying rocks to weathering. SagamuPapalanto study area is enclosed in the north by Oyo and Osun States, in the south by Lagos State in the east by Ondo State and in the west by Benin Republic. The study area belongs to the Ewekoro Formation which is Tertiary formed during the Paleocene and Eocene period (Ako et al. 1980; Omatsola and Adegoke 1981; Okosun 1990). The studied area is located on the sedimentary Formation of the south western Nigeria and it is underlain by the basement complex Adegoke et al. (1976). The geology of the area comprises of sedimentary units which consists of argillaceous sediment which is soft and friable and some siliceous and ferruginous materials (Fig. 1). The surface soils in the study area are residual lateritic materials composed of greyish to reddish brown, loose medium 


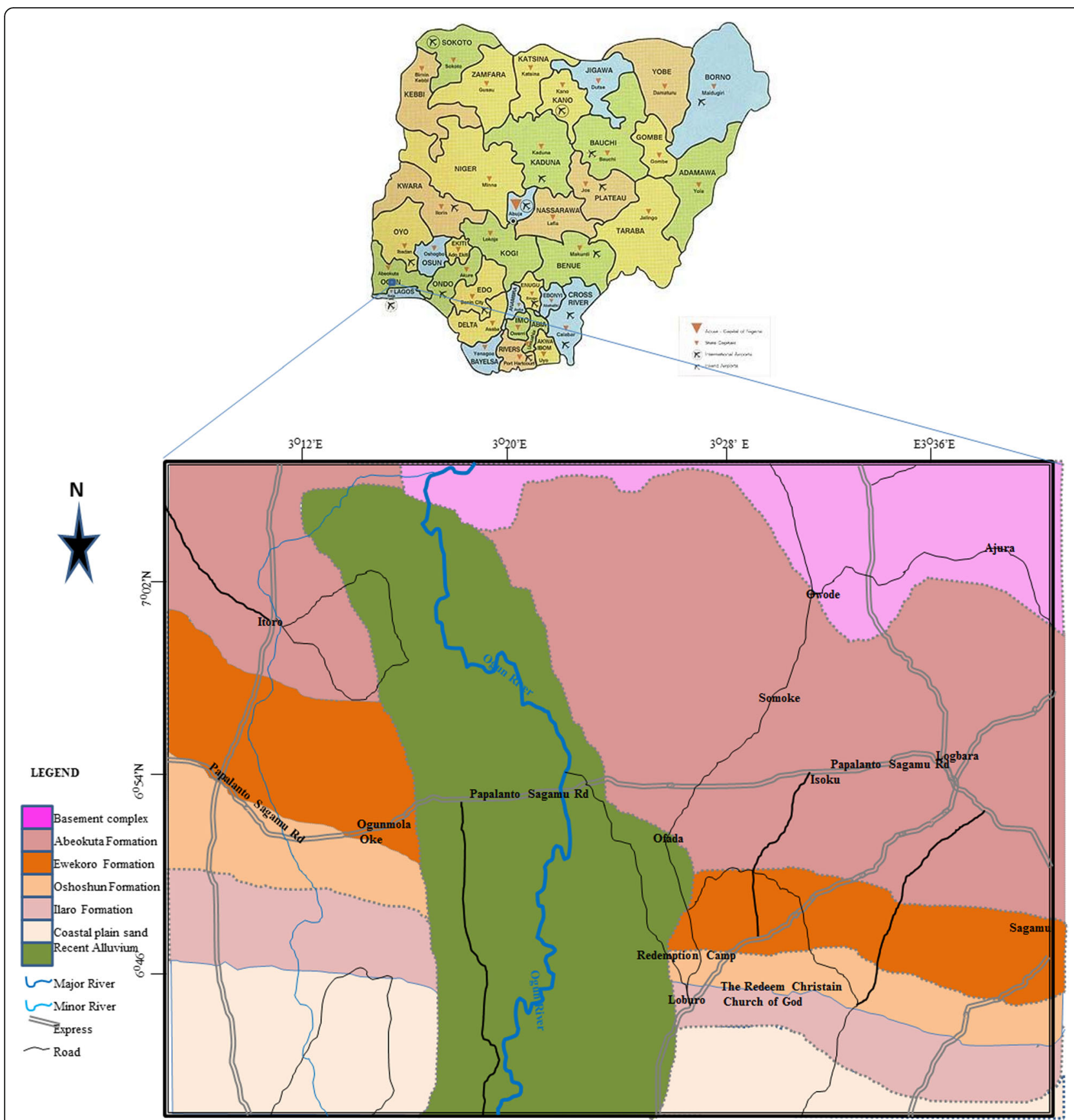

Fig. 1 Map of Nigeria and Geology of the Study Area

to coarse grained mineral matters with some clayey materials. The soils are however dark in colour in areas with vegetation cover probably as a result of decomposing flora and fauna.

\section{Materials and methods}

Visual inspection and reconnaissance survey were undertaken in the course of the fieldwork on February 2-February 102,020 , to evaluate and access the physical conditions of the highway pavements. The underlying rocks were identified and their structural trends were noted. Twenty disturbed soil samples were collected using an auger from the subgrade, subbase and base course. The materials were taken along the road sides adjacent to the failed sections in such a manner that the soil samples represent the different topographic condition of the road alignment. The samples collected were sent to the Lagos state material testing laboratory Nigeria for geotechnical analyses.

Electrical Resistivity Imaging (ERI) was implemented during the investigation. It is a geo-electrical technique 
used in acquiring a high-level resolution (2D) image of the earth surface using the Wenner array electrical configuration. The materials used include ABEM terra meter SAS 1000, measuring tape, masking tape, hammers electric, cable steel electrode, RES2DINV software, Global Positioning Satellite (GPS). The Wenner array method was used in the investigation. A spacing of $25 \mathrm{~m}, 35 \mathrm{~m}, 45 \mathrm{~m}$, $55 \mathrm{~m}, 65 \mathrm{~m}, 75 \mathrm{~m}, 85 \mathrm{~m}, 95 \mathrm{~m}, 105 \mathrm{~m}$ long stretch was employed. Traverse I, II III and IV were set -up laterally along the road profile that shows serious cracks and babbling of the pavement. Contrasting electrode spacing of $10 \mathrm{~m}, 20 \mathrm{~m}, 30 \mathrm{~m}$ and $40 \mathrm{~m}$ were employed accordingly for the electrode spread. Four horizontal profiles were set up, each had a length of $250 \mathrm{~m}$ and $600 \mathrm{~m}$ for transverse 4 . These was used for convenience of space due to vehicular movement. The data gathered from the field was ascribed into the software RES2DINV to create a $2 \mathrm{D}$ resistivity image of the earth subsurface under study. These results acquired was used to derive the qualitative exposition of the profiles. The result acquired from the study were plotted in form of a pseudo-section which gives an estimated near picture of the subsurface attribute and thereafter appraised to delineate the geo-electric properties of the section of the road in the study area.

The Cone Penetrometer Test (CPT) were carried out in accordance with the British Standard Code of Practice for Site Investigations, B. S 5930:1999 and with Method of Testing Soils for Civil Engineering Purposes, B. S 1377: 1990. The bearing capacity of the soil from the CPT was arrived at by using the established standard used by Lagos State Material Laboratory test for CPTs in foundation engineering, "Simplified Description of the use and Design Methods".
Eight soil samples were randomly selected for geochemical and mineralogical analysis. The samples were analyzed at the chemistry department of the university of Lagos. These tests were carried out by means of X-ray diffraction and Florescence (XRD/ XRF) methods after the techniques of (Carrol 1971). The clays minerals were recognized and the percentage abundance was calculated using the area method (International Joint Committee Properties on Mineral Powder Diffraction Standard 1980).

The natural moisture content of each of the samples collected was determined immediately it was taken to the laboratory. This was followed by air drying of all the samples for 1 week to obtain fairly constant moisture content. The geotechnical tests were carried out in accordance to (ASTM D6913-04, 2009) for Sieve analysis, (ASTM D4318-10, 2015) Atterberg's Consistency Limit tests, (ASTM D854-10, 2015; ASTM D854-14, 2015) Specific Gravity, (ASTM D698, 2015) Compaction, and (BS1377) California Bearing Ratio (CBR) tests. The detailed methods of these geotechnical analysis are highlighted in (Arora 2009).

\section{Results and discussion}

\section{The road conditions}

The road is a flexible pavement that is made up of the subbase, subgrade, base and the wearing course. The subgrade is the natural soil that act as foundation and is directly overlain by the subbase. The base of the road consists of aggregates whereas the wearing course made up of bitumen. Field observation shows that a significant portion of the road has failed. The distress was obvious in different forms which include; rutting, raveling, cracks and pothole (Fig. 2). In some segment of the road;

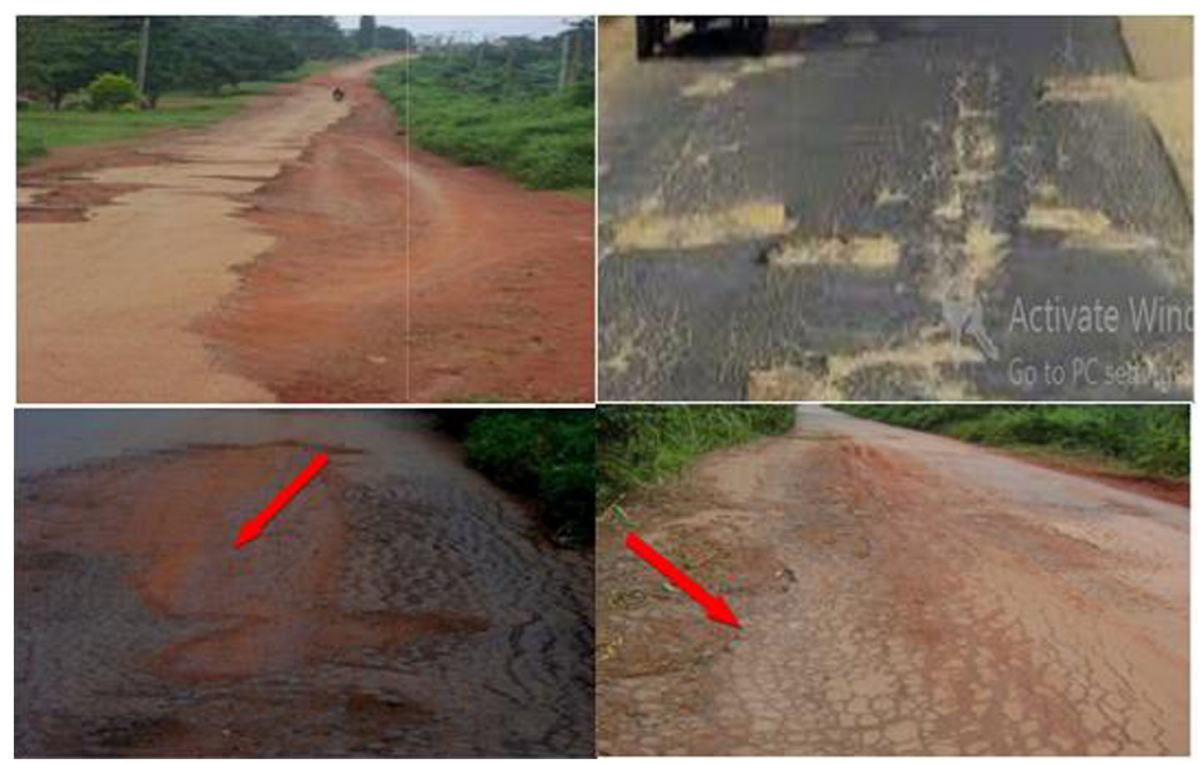

Fig. 2 Showing road failure in the study location 
corrugation, potholes and cracks often gets up to 1.5-2 $\mathrm{m}$ in wide and $1 \mathrm{~m}$ deep (Fig. 2). It was observed that the road is completely devoid of drainage facilities. The various types of failure encountered during the investigation are summarized in Table 1.

\section{D geo-electrical imaging of the study area}

Figure 3(a) represents the Pseudo-section from the apparent resistivity measurement along profile A. The plot revealed a resistivity value in the range of $1110 \Omega \mathrm{m}$ - $1576 \Omega \mathrm{m}$, between two major segments at distances ranging from 10 to $90 \mathrm{~m}$ and $110 \mathrm{~m}-170 \mathrm{~m}$ along the profile to a depth of $2.50 \mathrm{~m}-11.02 \mathrm{~m}$ and $2.50 \mathrm{~m}-15$ $\mathrm{m}$ respectively. The arrows showed sections along the profiles with low resistivity. Figure 3(b) shows the representation of the Pseudo-section from the calculated apparent resistivity. The resistivity values are similar to the results obtained along the profile in Fig. 3(a). Figure 3(c) is the inverse model of the $2 \mathrm{D}$ resistivity sections along the profile. Two distinctive zones were delineated with low resistivity values along profile A. This occurred at the distance between $122.5 \mathrm{~m}-130.0 \mathrm{~m}$ along the profile to a depth of $5 \mathrm{~m}$ from the top soil. It was also revealed that at a distance of $200 \mathrm{~m}-235 \mathrm{~m}$, moderate resistivity values in the range of $1200 \Omega \mathrm{m}-1600 \Omega \mathrm{m}$ which terminate at a depth of $18 \mathrm{~m}$ from the surface of the profile was delineated.

Figure 4(a) represents the Pseudo-section from the apparent resistivity measurement along profile $\mathrm{B}$. The plot revealed a resistivity value in the range of $100 \Omega m-300$ $\Omega \mathrm{m}$, between a distance of $20 \mathrm{~m}-240 \mathrm{~m}$ along the profile to a depth of $7.60 \mathrm{~m}$ from the surface of the profile. Figure 4(b) shows the representation of the Pseudo-section from the calculated apparent resistivity. The section reveled low resistivity values in the same section along the profile similar to that of Fig. 4(a). Figure 4(c) is the inverse model of the $2 \mathrm{D}$ resistivity sections along the profile. Low resistivity values were observed in different sections of the model along the profile, few sections along the profile showed a resistivity value that is greater than $200 \Omega \mathrm{m}$. Two distinct sections along the profiles with very low resistivity values at a distance of $10-45 \mathrm{~m}, 60-110 \mathrm{~m}$ and $180-235 \mathrm{~m}$ to a depth of $7.60 \mathrm{~m}, 2.80 \mathrm{~m}$ and $5.60 \mathrm{~m}$ respectively were also delineated.

Table 1 Showing the locations of distress in the study area

\begin{tabular}{|c|c|c|c|c|}
\hline & Coordinates & Failure type & Location & Remark \\
\hline 1 & $\begin{array}{l}3^{\circ} 23^{\prime} 29.627 " \mathrm{E} \\
6^{\circ} 53^{\prime} 1.217^{\prime \prime} \mathrm{N} \\
3^{\circ} 33^{\prime} 19.68^{\prime \prime} \mathrm{E} \\
6^{\circ} 53^{\prime} 12.48 " \mathrm{~N} \\
3^{\circ} 24^{\prime} 27.36^{\prime \prime} \mathrm{E} \\
6^{\circ} 53^{\prime} 46.48 " \mathrm{~N} \\
3^{\circ} 24^{\prime} 17.12^{\prime \prime} \mathrm{E} \\
6^{\circ} 53^{\prime} 17.38^{\prime \prime} \mathrm{N}\end{array}$ & Cracks & $1,2,11,20$ & Seriously cracked with the bituminous layer completely altered. \\
\hline 2 & $\begin{array}{l}3^{\circ} 17^{\prime} 38.27^{\prime \prime} \mathrm{E} \\
6^{\circ} 52^{\prime} 46.56^{\prime \prime N} \mathrm{~N} \\
3^{\circ} 19^{\prime} 22.08^{\prime \prime} \mathrm{E} \\
6^{\circ} 52^{\prime} 46.56^{\prime \prime} \mathrm{N} \\
3^{\circ} 19^{\prime} 22.08^{\prime \prime} \mathrm{E} \\
6^{\circ} 52^{\prime} 46.56^{\prime \prime} \mathrm{N} \\
3^{\circ} 17^{\prime} 12.48^{\prime \prime} \mathrm{E} \\
6^{\circ} 52^{\prime} 64.56^{\prime \prime} \mathrm{N} \\
3^{\circ} 16^{\prime} 46.56^{\prime \prime} \mathrm{E} \\
6^{\circ} 52^{\prime} 20.64^{\prime \prime} \mathrm{N}\end{array}$ & Potholes & $4,5,7,9,19$ & $\begin{array}{l}\text { Crater shaped defect with fairly extensive with in some places } \\
\text { cutting as deep as } 0.5 \mathrm{~m} \text { in some of the locations. It retains } \\
\text { considerable quantity of rain water and provide an easy passage } \\
\text { for the entry of rainwater }\end{array}$ \\
\hline 3 & $\begin{array}{l}3^{\circ} 15^{\prime} 28.47^{\prime \prime} \mathrm{E} \\
6^{\circ} 51^{\prime} 54.72^{\prime \prime} \mathrm{N} \\
3^{\circ} 13^{\prime} 19.04^{\prime \prime} \mathrm{E} \\
6^{\circ} 52^{\prime} 20.64^{\prime \prime} \mathrm{N} \\
3^{\circ} 11 ' 35.52^{\prime \prime} \mathrm{E} \\
6^{\circ} 53^{\prime} 35.52^{\prime \prime} \mathrm{N} \\
3^{\circ} 12^{\prime} 10.41^{\prime \prime} \mathrm{E} \\
6^{\circ} 52^{\prime} 47.50^{\prime \prime} \mathrm{N} \\
3^{\circ} 22^{\prime} 26.88^{\prime \prime} \mathrm{E} \\
6^{\circ} 52^{\prime} 34.57^{\prime \prime} \mathrm{N} \\
3^{\circ} 15^{\prime} 28.18^{\prime \prime} \mathrm{E} \\
6^{\circ} 52^{\prime} 46.32^{\prime \prime} \mathrm{N} \\
3^{\circ} 16^{\prime} 20.54^{\prime \prime} \mathrm{E} \\
6^{\circ} 52^{\prime} 20.64^{\prime \prime} \mathrm{N} \\
3^{\circ} 53^{\prime} 12.22^{\prime \prime} \mathrm{E} \\
6^{\circ} 52^{\prime} 53.22^{\prime \prime} \mathrm{N} \\
3^{\circ} 34^{\prime} 42.24^{\prime \prime} \mathrm{E} \\
6^{\circ} 53^{\prime} 12.48^{\prime \prime} \mathrm{N}\end{array}$ & Corrugation and Raveling & $3,8,6,10,12,14,16,17,18$ & $\begin{array}{l}\text { The portion are fully broken down with the structural } \\
\text { components of the road entirely pulled out and removed }\end{array}$ \\
\hline
\end{tabular}




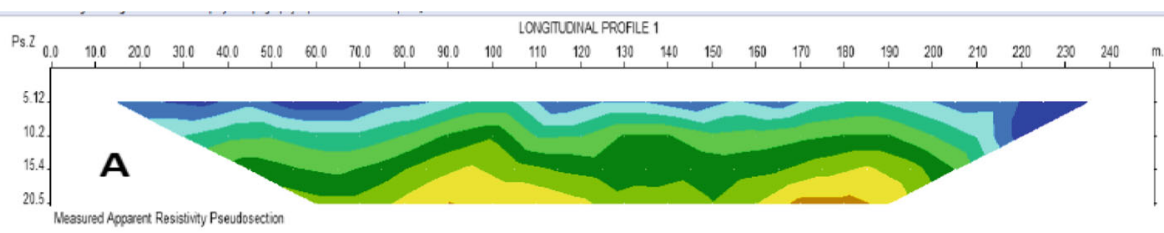

a: Measured apparent resistivity of profile A.

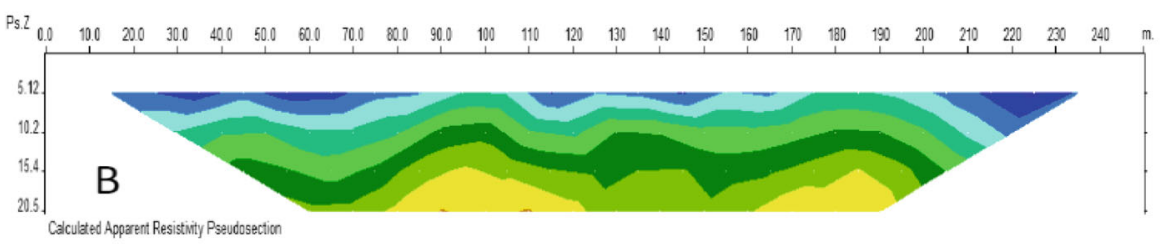

b: Calculated apparent resistivity of profile $A$

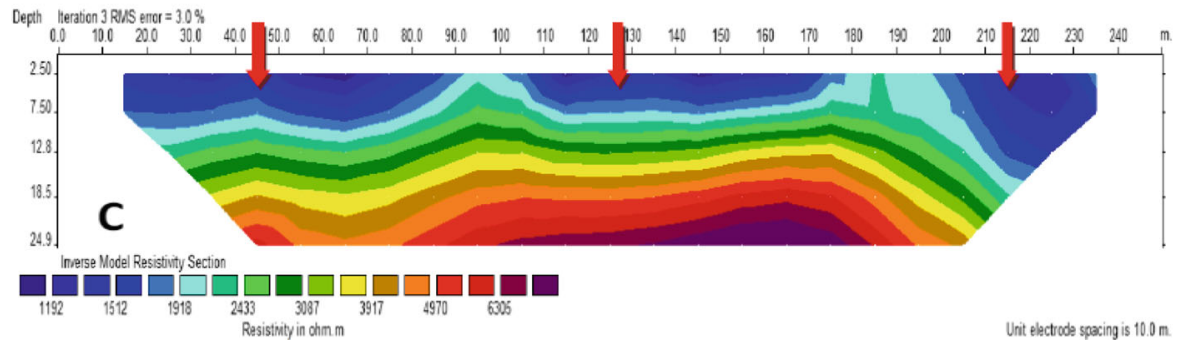

c: Inverse model resistivity section of profile $A$.

Fig. 3 Resistivity model for profile A

Figure 5(a) represents the Pseudo-section from the apparent resistivity measurement along profile C. Low resistivity value with the range of $50 \Omega \mathrm{m}-111 \Omega \mathrm{m}$, at a distance of $80 \mathrm{~m}-120 \mathrm{~m}$ along the profile to a depth of $15 \mathrm{~m}$ from the surface of the profile were observed. Figure 5(b) shows the representation of the Pseudosection from the calculated apparent resistivity. The section revealed low resistivity values that is similar to what was obtained for the profile section in Fig. 5(a). Figure 5 (c) shows the inverse model of the $2 \mathrm{D}$ resistivity sections along the profile. Low resistivity values were observed along the major sections. Very low resistivity values were observed at two distinctive zones from a distance of 40.0 - $140 \mathrm{~m}, 190.0-210.0 \mathrm{~m}$ to a depth of $21 \mathrm{~m}$ and $25 \mathrm{~m}$ respectively.

Figure 6(a) represents the Pseudo-section from the apparent resistivity measurement along profile $\mathrm{D}$. The plot revealed a low resistivity value in the range of $100 \Omega \mathrm{m}-$ $350 \Omega \mathrm{m}$, at a distance of $10 \mathrm{~m}-500 \mathrm{~m}$ along the profile to a depth of $13 \mathrm{~m}$ from the surface of the profile. Figure 6(b) shows the representation of the Pseudo-section from the calculated apparent resistivity. The section revealed a low resistivity values that is similar to what was obtained for the profile section in Fig. 6(a). Figure 6(c) shows the inverse model of the $2 \mathrm{D}$ resistivity sections along the profile. Low resistivity values were delineated to depth of $15 \mathrm{~m}$ along the section. The implication of the low resistivity values as revealed from the sections signifies that the soils in the region are of poor foundation materials and not competent to withstand imposed load.

The Cone Penetration Test (CPT) curves for the studied soils are shown (Fig. 7) and the results of the CPT are shown in Table 2. The test was carried out to determine the strength of near surface materials and also access the in-situ strength of the soil. The results revealed a low cone resistance value which indicates clayey sand material for sampling points 1, 2, 3 and 4. The linear natures of the curves in sample point 3 and 4 as shown in (Fig. 7) revealed that the subsurface materials offer no resistance to the driven cone when compared to the curve plotted for sample point 1 . The CPT depth values for the locations are in the range of $2-16 \mathrm{~m}$. The depth of penetration that offers no resistance as shown in (Fig. 7) shows that the area is unfit for erecting foundation. Erecting foundation on the subgrade soil without applying the necessary treatment would result to the soil collapsing under an imposed load. The low value of the shear strength also 


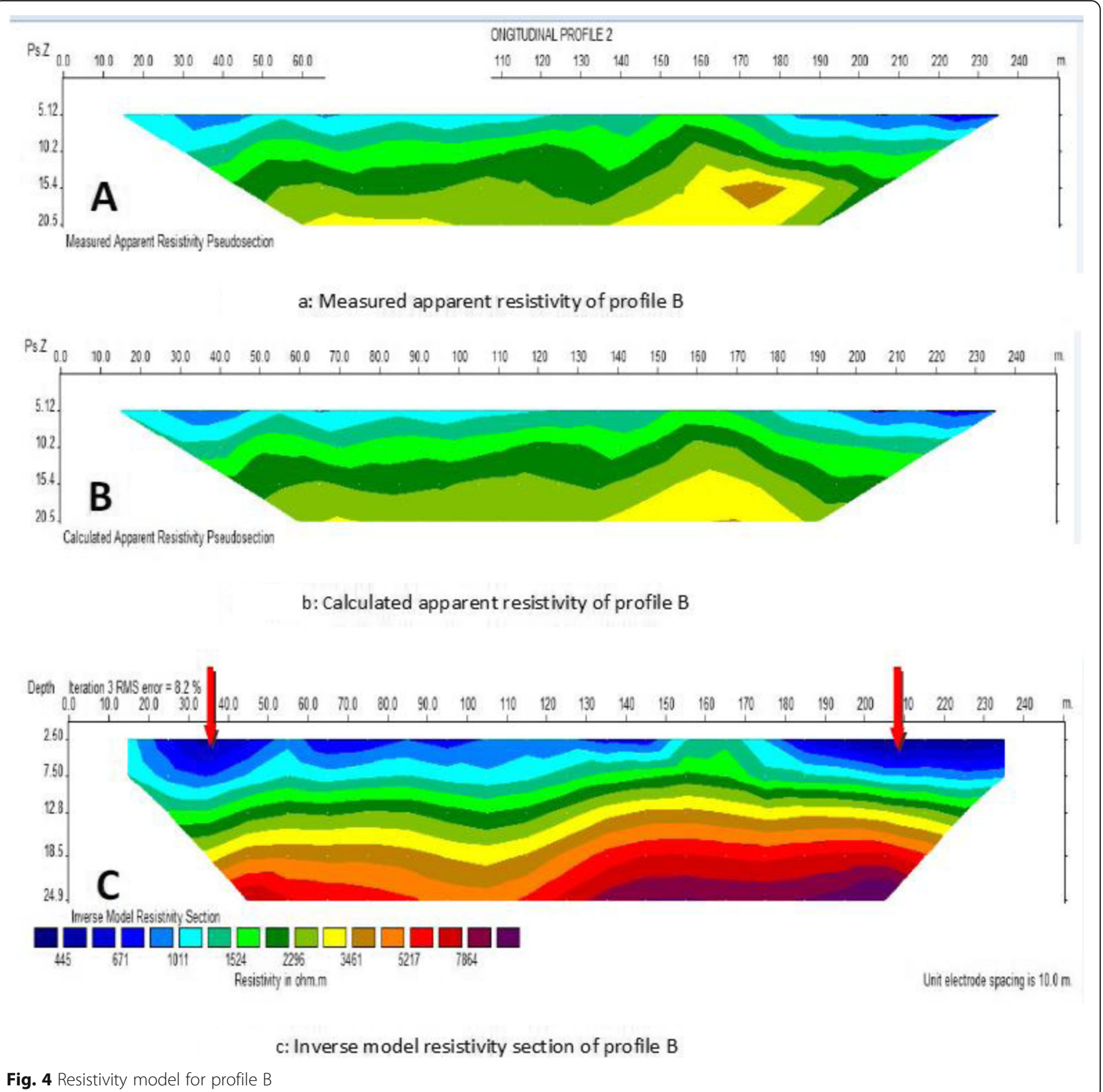

revealed that the materials are undesirable as subgrade materials for road pavement. The implication of this is that the materials will expand and contract under diverse weather conditions.

The bearing capacity of the soil was derived using the following equation:

Undrained shear strength $(\mathrm{Cu})$

$$
\mathrm{Cu}=\mathrm{qc} / \mathrm{Nk}
$$

Where qc $=$ cone end resistance value $\mathrm{Nk}=$ Point of refusal or termination point Allowable Bearing Capacity
Ultimate bearing capacity is $5.14 \times \mathrm{Cu}$, where 5.14 is constant

Allowable bearing capacity $=5.14 \times \mathrm{Cu} / 3$

Geochemical and mineralogical properties of the selected soil samples

Table 3 shows the mineralogical properties of the selected eight samples. The prominent clay mineral types obtained are quartz, illite, kaolinite and dickite. There was no presence of montmorillonite and smectite which is accordance with was reported by (Okogbue 1988) that 


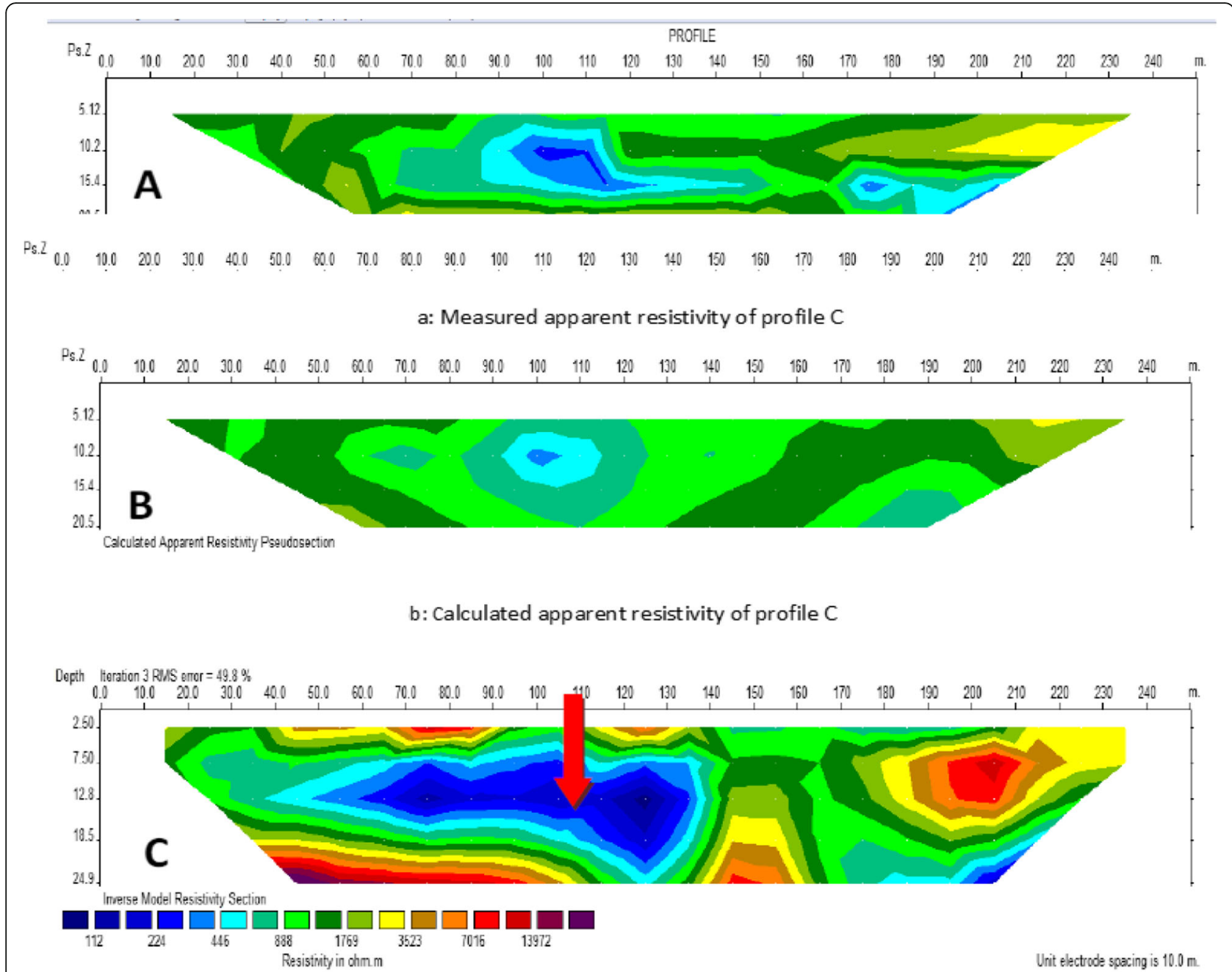

c: Inverse model resistivity section of profile C

Fig. 5 Resistivity model for profile C

montmorillonite is not present in the south western Nigerian soils studied. The results of the mineralogy are also in accordance with the results obtained in Table 4 which revealed that the soils are of low to medium plasticity. This is also in affirmation to the presence of kaolinite which occurred as the major mineral in Table 3. Since kaolinites has the least affinity for water among the clay minerals, the studied soil will exhibit moderate expansion in the presence of water. The results revealed that the soils have low affinity for water and are well drained. However, the occurrence of muscovite in some location may result to field compaction issue (Gidigasu 1976; Ogunsanwo 1988; Onana et al. 2017).

The result of geochemical analysis is presented on Table 3. The main total chemical elements present in the studied soils in decreasing order are $\mathrm{SiO}_{2}, \mathrm{Al}_{2} \mathrm{O}_{3}$, and $\mathrm{Fe}_{2} \mathrm{O}_{3}$ with averages of $44.77 \%, 21.9 \%$ and $21.60 \%$ respectively. The studied soil samples are characterized by high amounts of silica from 40.54-53.98\%, appreciable amount of sesquioxides $\left(\mathrm{Al}_{2} \mathrm{O}_{3}\right.$ and $\left.\mathrm{Fe}_{2} \mathrm{O}_{3}\right)$ in the range of $17.10-29.5 \%$ for $\mathrm{Al}_{2} \mathrm{O}_{3}, 2.87-29.41 \%$ for $\mathrm{Fe}_{2} \mathrm{O}_{3}$ and reasonable amount of bases $\left(\mathrm{K}_{2} \mathrm{O}\right.$ and $\left.\mathrm{CaO}\right)$. The other chemical element concentrations were all lower than 5\% (Table 6). The silica(S)/sesquioxides ratios(R) (Table 3) ranges from 0.81-1.67.BS 1377 (1990) and Onana et al. (2017) classified soils based on the silica/ sesquioxides ratio as laterite if the is less than 1.33; lateritic if ratio ranges from 1.33 to 2 and non-lateritic if it is greater than 2. According to this classification, $5 \%$ of the studied soils are classified as non-lateritic soils while the rest $95 \%$ are classified as lateritic. This result is in line with the expected condition of leaching in a warm environment like the study area (Loughnan 1969) where silica is leached away from decaying silicate rocks concentrating secondary minerals like oxides of iron and aluminum as well as kaolinite in the soil. 


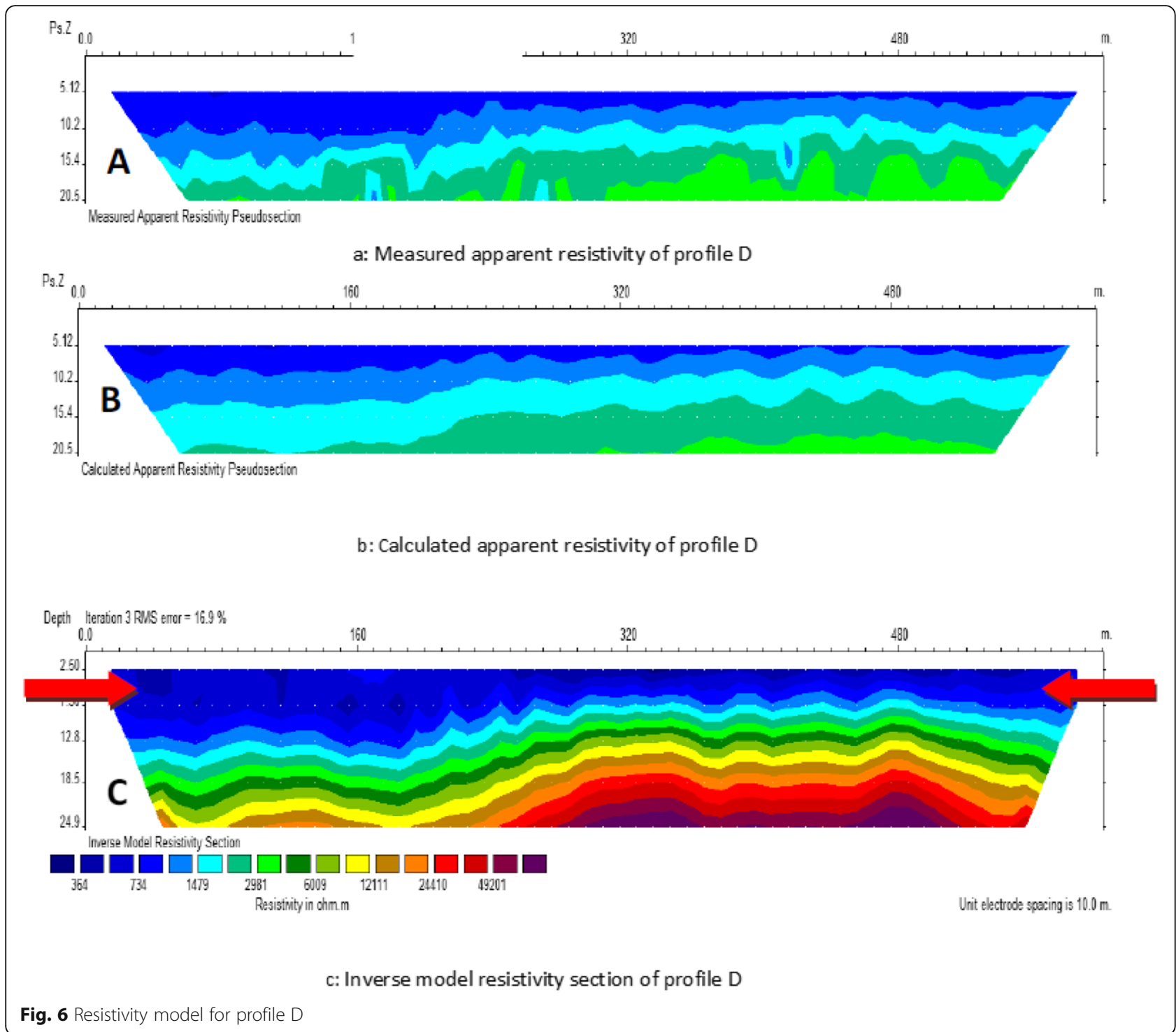

\section{Geotechnical properties of the soils}

The results of the natural moisture content of the investigated soil are shown in Table 4. The natural moisture content plays an important role in increasing or reducing density indices of soils and it varies based on the depth of the soil, previous rainfall data and the existing drainage conditions (Ramamurthy and Sitharam 2005). The moisture content is one of the components that affect the dry density of soils (Garber and Hoel 1999). The periodic rainfall fluctuations in the moisture contents of soil will result to a large volume changes in the clayey soils. The natural moisture content of the analyzed soil samples varied from 9.4 to $18.2 \%$ for subgrade, from $7.5 \%$ and $15.4 \%$ for base course between $6.8 \%$ and $19.7 \%$ for sub-base course (Table 4). It was revealed that six sample locations values are higher than the specified value of (5-15\%) recommended by the (FMWH 1997) for road construction. This shows high water adsorption potential of the soil materials. The results revealed that the values obtained will lead to reduction in shear strength (Ademilua 2018). Thus, they are unfit as subgrade, subbase and base materials. High fluctuation in moisture content often results to a large volume changes in the clayey soils (Daramola et al. 2018). The results obtained for the moisture content ranges from favorable, marginal favorable to unfavorable in accordance to (Underwood 1967).

The results of the grain size distribution are summarized in Table 4. The grain size analysis is important in determining the strength of the soil and also determine the particle size distribution of the studied soils (Naresh and Nowatzki 2006). The results show the percentage amount of clays, silts, fines, sand and gravel ranged from $12.1-27.5 \%, 6.1-15.8 \%, 12-38.5 \%, 49.4-80.1 \%$ and $4.7-$ 


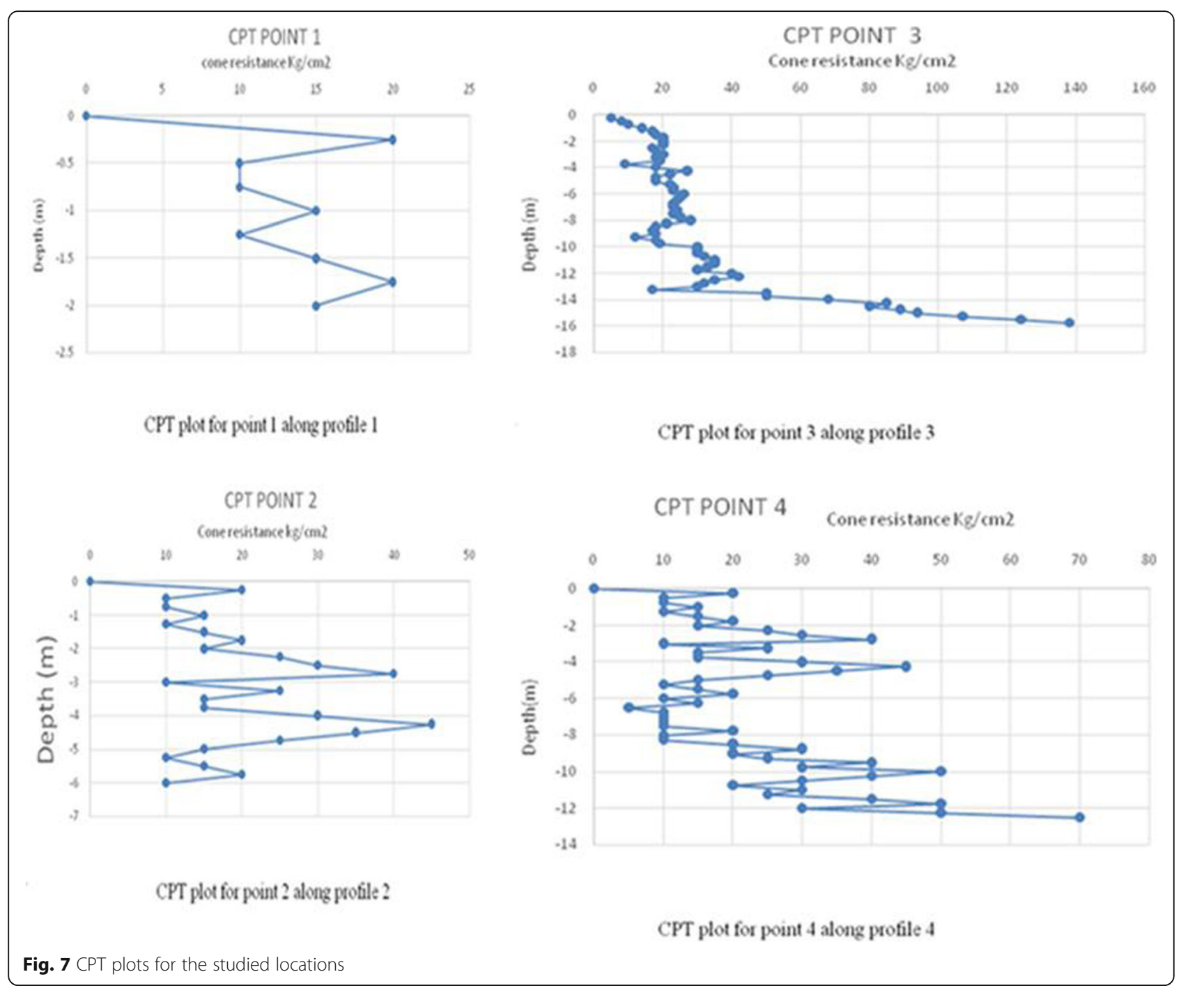

$20.2 \%$ for subgrade, $18.5-39 \%, 7.4-37.2 \%, 30.2-62.8 \%$, $36-63.4 \%$ and $3.2-13.2$ for subbase course and 26.2$48.9 \%, 11.2-16.4,36.1-58.0 \%, 31.7-61.3 \%$ and $2.7-25.9 \%$ for base course. FMWH (1997) recommends subgrade soils to possess less than $35 \%$ amount of fines. The results obtained in comparison with FMWH (1997) shows that four soil samples did not meet up the specification. It can be inferred from the result that the soils are susceptible to frequent shrinkage and swelling potentials during the variation in climatic seasons which are usually the characteristics of the environmental condition of the study location. The high percentage of fines had

Table 2 Results of CPT for the studied locations

\begin{tabular}{|c|c|c|c|c|}
\hline Location & CPT point 1 & CPT point 2 & CPT point 3 & CPT point 4 \\
\hline Test Hole & CPT 1 & CPT 2 & CPT3 & CPT 4 \\
\hline Depth of Penetration (m) & 2 & 6 & 16 & 12.5 \\
\hline Cone Resistance $\left(\mathrm{kgf} / \mathrm{cm}^{2}\right)$ & 20 & 45 & 138 & 72 \\
\hline Undrained shear strength $(\mathrm{Cu}) \mathrm{KN} / \mathrm{m}^{2}$ & 10 & 7.50 & 8.63 & 5.76 \\
\hline Allowable bearing capacity $\mathrm{KN} / \mathrm{m}^{2}$ & 17.13 & 12.85 & 14.77 & 9.86 \\
\hline Ultimate bearing capacity & 50 & 37.5 & 43.125 & 28.5 \\
\hline Remarks & $\begin{array}{l}\text { Dark grey, stiff medium } \\
\text { grained clayey sand }\end{array}$ & $\begin{array}{l}\text { Dark grey, medium } \\
\text { grained clayey sand }\end{array}$ & $\begin{array}{l}\text { Dark grey, stiff, fine-medium } \\
\text { grained Clayey sand }\end{array}$ & $\begin{array}{l}\text { Dark grey, stiff, fine-medium } \\
\text { grained Clayey sand }\end{array}$ \\
\hline
\end{tabular}




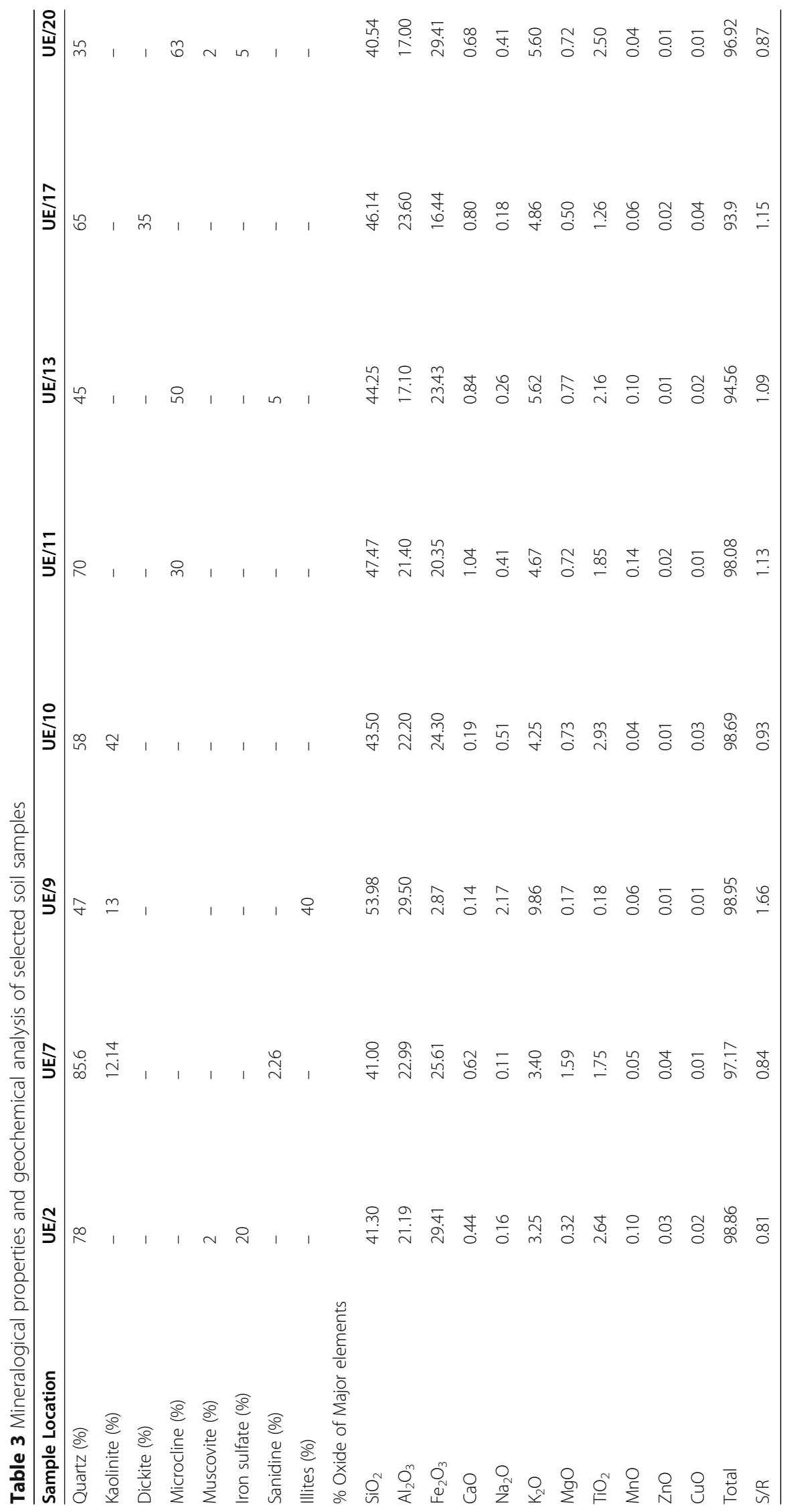




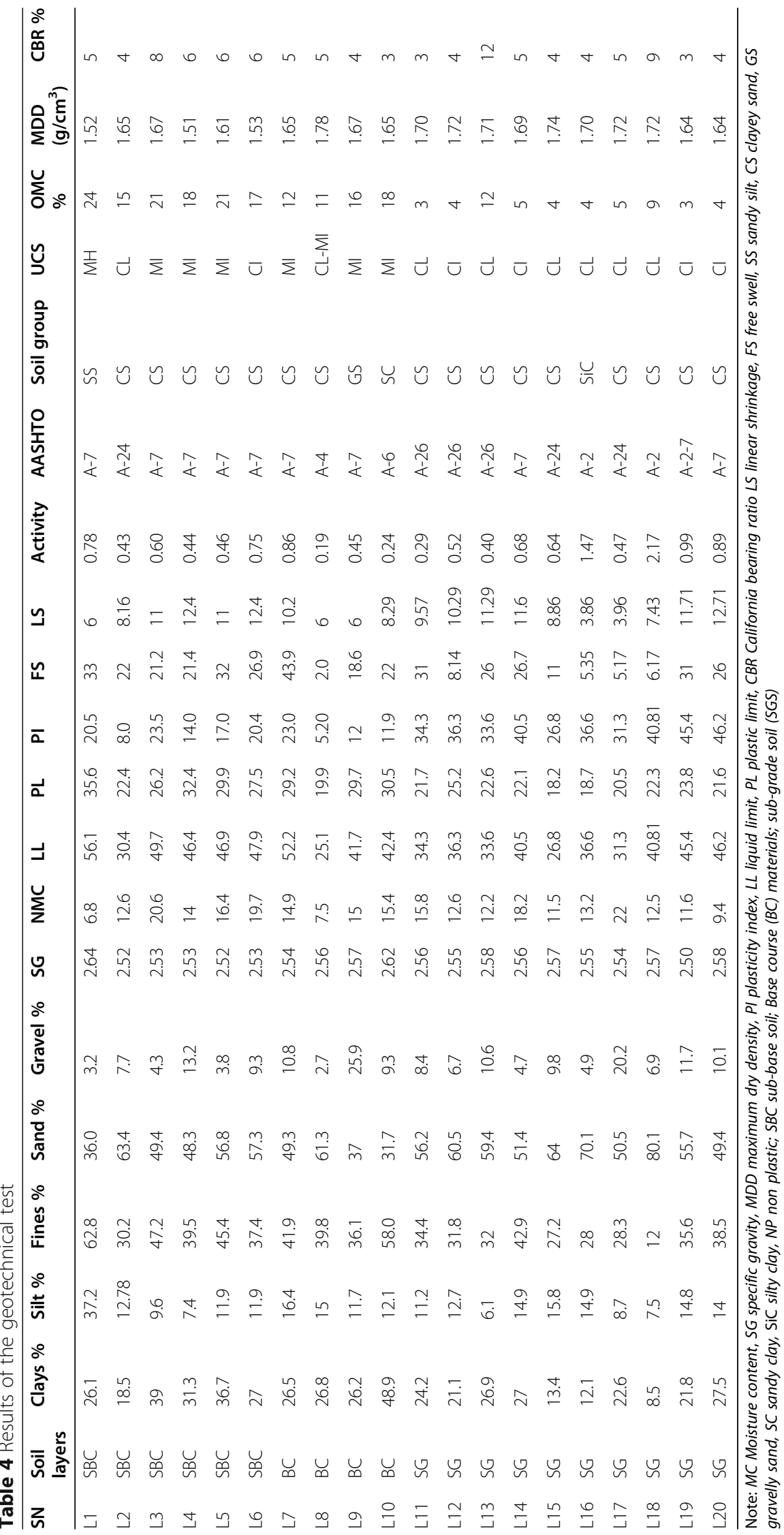


been linked to the predominance of clay which feasibly exerts a dominant control on the mass behavior of soil which makes it mechanical unfit. The results from the study shows that that $60 \%$ did not meet the requirement for subgrade soil while $40 \%$ meet the condition when compared with (Underwood 1967) which states that subgrade soils have less than $35 \%$ fines. The group index is the parameter that gives an indication of the load bearing capacity within the AASHTO soil group. The resulting increase in the group index will cause decrease in the load carrying capacity. The results on the studied samples (Table 4, Fig. 8) revealed that the soils are classified as A-26, A-24, A-2 and A-7 according to AASHTO (1993). The soils in these groups are considered as clayey soils. The soils are grouped as fair to poor materials for road construction. The soils classified as A-2-7 soil on AASHTO soil classification is regarded as poorly graded and poor graded (GP) on USCS soil classification with group index of 0 (Gopal and Rao 2011). Therefore, they are unfit for use as subgrade, subbase and base road construction materials. The clayey soils are classified as fair to poor road materials, while the granular soils are classified as excellent or good road materials.

The consistency limits are used in determining the settlement and strength characteristics of soils for road construction (Sowers and Sowers 1970; Adeyemi 1995). The liquid, plastic limit and plasticity index results of the studied soils ranged from $25.1 \%-52.2 \%, 19.9 \%-$ $30.5 \%$ and $5.20-23.0 \%$ for base course, $30.4-56.1 \%$, $22.4 \%-35.6 \%$ and $8.0-23.5 \%$ for subbase course and $26.8-46.2 \%, 18.2-25.2 \%$ and $7.1-24.6 \%$ for subgrade (Table 4). All the studied soils have the potentials of causing a major deformation under load due to their plastic natures. It is noteworthy that $95 \%$ of the studied soils are within (FMWH 1997) stipulated standard of $50 \%$ for liquid limit making them suitable as use for subgrade, sub-base and base materials for road construction. Moreover, only six of the studied samples fall within (FMWH 1997) stipulated for maximum plasticity index of $20 \%$ for highway subgrade materials, whereas the rest of the studied soil samples are above the stated recommended standard which makes it unsuitable for subgrade construction materials. (Ola 1983) stated that soils with plasticity index that is lower than $25 \%$ shows low to medium swelling potential.

The Casagrande's plasticity chart (Fig. 9) is also used soil classification (Cassagrande 1947). The studied soil samples fall within the $\mathrm{CI}, \mathrm{CL}$ and $\mathrm{CH}$. These soils are grouped on the basis of their liquid limit and plasticity index. Two of the studied soil samples are within the low plasticity (CL) whereas eighteen of the studied soil samples falls within the medium to high plasticity (CI) categories on the Casagrande's chart. The results revealed that $64 \%$ of the soils were plotted within the field of inorganic silts while $36 \%$ were plotted in the field of inorganic clays. Additionally, when the plasticity index lies between 20 and 35\% then it satisfies the condition for high swelling potential and between 25 and $41 \%$ for a high degree of expansion (Gopal and Rao 2011). The plasticity index is a predominant factor used in the selection of materials for subgrade and subbase. It gives much detailed facts on the properties and behavior of clays in contrast to grain size data (Lambe 1951). Excessive plasticity often leads to fluctuations which arises from plastic flow upon the application of axle load

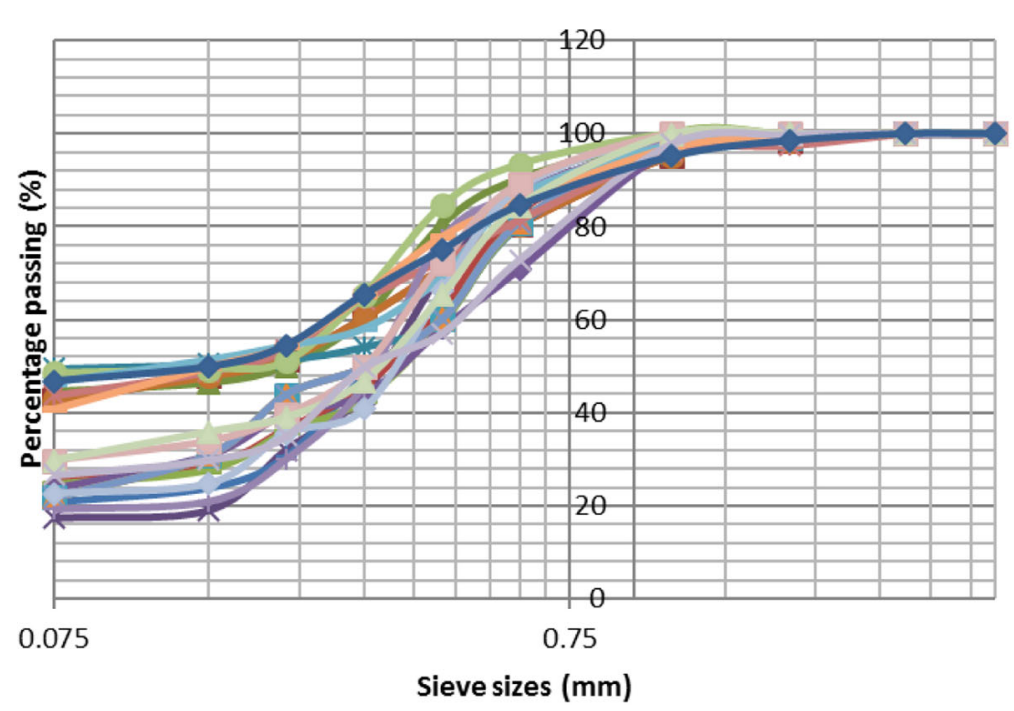

Sieve sizes $(\mathrm{mm})$

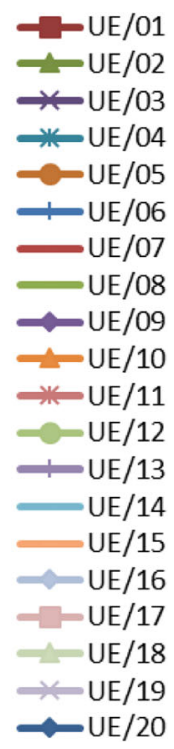

Fig. 8 Stacked grain size distribution for samples UE1-20 


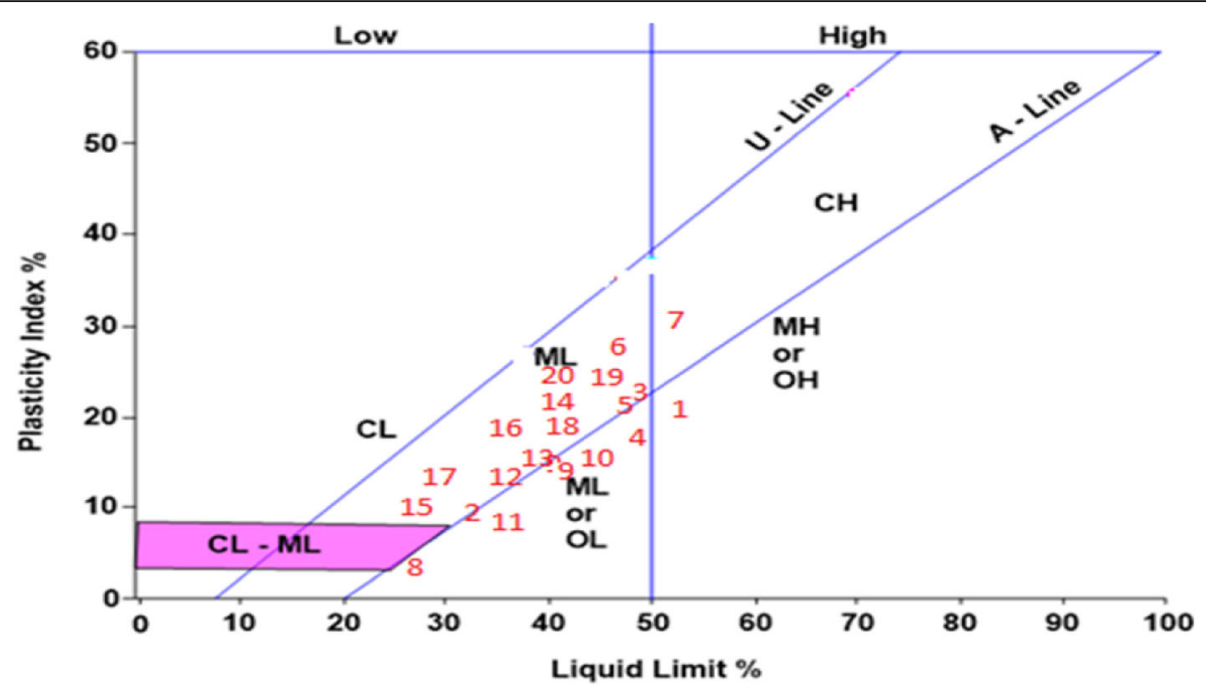

Fig. 9 Plasticity chart of the studied soil samples (Cassagrande 1947)

(Adeyemi 1995, 2002). Soils with extremely high liquid limit are often prone to have low bearing capacity. Cassagrande (1947) stated that soil samples with low, medium and high plasticity will have low, medium and high compressibility respectively Table 5 .

The linear shrinkage of the soils varied from 6 to $12.4 \%$ for subbase course, $6-10.2 \%$ for base course and $3.86-14.4 \%$ for subgrade (Table 4). Brink et al. (1982) and Ola (1983) reported that soils with linear shrinkage values exceeding $8 \%$ will be active, have a serious swelling potential and unsuitable as foundation materials Table 6. Gidigasu (1973) reported that soils having linear shrinkage value greater than $10 \%$ will constitute a field compaction problem. It was revealed that $70 \%$ of the studied soil samples will constitute a field compaction problem. It was revealed from the results that seven samples from the subgrade samples have values greater than (Madedor 1983; Jegede 2004) as stipulated which states that $8 \%$ is the maximum value that is required for subgrade soils as use for road construction. The implication of the results is that during seasonal fluctuation in weather condition (the wet and dry seasons) the soils will experience swelling and shrinkage. This is also evident in the tropical climatic weather condition that is often associated with the study location. From the results of the linear shrinkage, it is noteworthy that only three sample locations met the requirements for road construction and the rest of the samples did not meet the stated specification (FMWH 1997). The soils that are linked to excessive shrinkage and swelling can be reworked to have the required needed characteristics for road construction by stabilizing it (Olofinyo et al. 2019).

The values of the specific gravity of the studied soil range from 2.52-2.64 for subbase course, 2.54-2.62 for base course and 2.54-2.58 for subgrade (Table 4). The specific gravity is known to link the strength of soil and are in turn used as criteria for selecting an appropriate material for highway pavement construction materials especially when used along with other pavement materials. Low specific gravity is connected with clay mineralogy and weathering of feldspar that gave rise to the clay (Okogbue 1988; Owoyemi and Adeyemi 2012). The value is low when compared with the residual soils within the basement complex of Nigeria (Jegede 1998). It has been revealed by (Gidigasu 1983; Kabir and Taha 2004) that specific gravity has strong correlation between the chemical composition and the mineralogy of a soil. Gidigasu (1983) reported that the greater the specific gravity; the greater the degree laterization. The more the percentage of clay fraction and alumina concentration the less the specific gravity. The studied soils have been grouped as inorganic soils (Ramamurthy and Sitharam 2005).

Table 5 Expansive soil classification based on plasticity index and Liquid

\begin{tabular}{|c|c|c|c|c|c|c|c|}
\hline Swell potential & Plasticity index (\%) & & & Swell potential & Liquid limit (\%) & & \\
\hline Holtz and Gibbs (1956) & Chen (1988) & IS:1498 (1970) & & Chen (1965) & Snethan et al. (1977) & IS: 1498 (1970) & \\
\hline Low & $<18$ & $0-15$ & $<12$ & Low & $<30$ & $<50$ & $35-50$ \\
\hline Medium & $15-28$ & $10-35$ & $12-23$ & Medium/marginal & $30-40$ & $50-60$ & $50-70$ \\
\hline \multirow[t]{2}{*}{ High } & $25-41$ & $20-55$ & $23-32$ & High & $40-60$ & $>60$ & 70-90 \\
\hline & & & & Very high & $>60$ & - & $20-35$ \\
\hline
\end{tabular}


Table 6 Expansive soil classification based on shrinkage limit

\begin{tabular}{llll}
\hline $\begin{array}{l}\text { Swell potential } \\
\text { (Holtz and Gibbs 1956) }\end{array}$ & Shrinkage limit (\%) & $\begin{array}{l}\text { Volume change } \\
\text { (Altmeyer 1956) }\end{array}$ & Shrinkage limit (\%) \\
\hline Low & $>15$ & Non-critical & $>12$ \\
Medium & $10-16$ & Marginal & $10-12$ \\
High & $7-12$ & Critical & $<10$ \\
Very high & $<11$ & Volume change & Shrinkage limit (\%) \\
\hline
\end{tabular}

Activity of the soil results are summarized in (Table 4). Clay activity of soils is obtained by integrating Atterberg limits and clay content into an exclusive parameter (Skempton 1953). The results of the percentage clay sized fraction and plasticity index were used to calculate the activity in order to determine the measure and the degree of likelihood of exhibiting colloidal behavior. This is linked to the geologic history and mineralogy of clays presents in the soils. The characteristics of clay soils are known by the physicochemical characteristics of the different constituents' minerals and by the relative proportions of the minerals present (Olofinyo et al. 2019). The activity values from the studied soil ranges from 0.19-2.17 (Table 4) which indicate active to inactive clays. Consequently, the studied soils have low - medium and negligible high expansion ability as derived from the activity chart (Fig. 10). Underwood (1967) proposed three classes of clay based on their activity which includes; the normal clays, active clays and inactive clays which ranges from $0.75-1.25$, value greater than 1.25 and value less than 0.75 . The activity less than 1 corresponds to kaolinite, while activity between 1 and 2 corresponds to illite and greater than 2 corresponds to montmorillonite (Skempton 1953). The results indicate that the predominant clay mineral present in the soil is kaolinite as eighteen samples location has clay activity values of less than one, which is inactivity and low moisture affinity.

The free swells results are summarized in (Tables 4), the values of the free swell index of the studied soil range from 5.17-43.9; The results show that the soils in the study area ranged from kaolinite and illite. It possesses low to medium swelling potential (Table 7). The results are in accordance with (Aghamelu and Okogbue 2011; Onana et al. 2017) on their research on the geotechnical properties of highway soils in southwestern and eastern Nigeria.

The compaction curves for the studied soils are shown in Fig. 11. The Optimum Moisture Content varied between 12 and 18\%, 15-24\%, 12-17\% for base course, sub base and sub grade respectively at the Maximum Dry Densities (MDD) of $1.65-1.78 \mathrm{~g} / \mathrm{cm}^{3}, 1.51-1.67 \mathrm{~g} / \mathrm{cm}^{3}$ and $1.64-1.74 \mathrm{~g} / \mathrm{cm}^{3}$ respectively Table 4 . The MDD of the base course is less than the specified value (i.e.>/ 2.0 $\left.\mathrm{g} \backslash \mathrm{cm}^{3}\right)$ in all the sample locations. It was revealed that five subgrade soils samples met the (FMWH 1997) specification which states that the MDD values should be

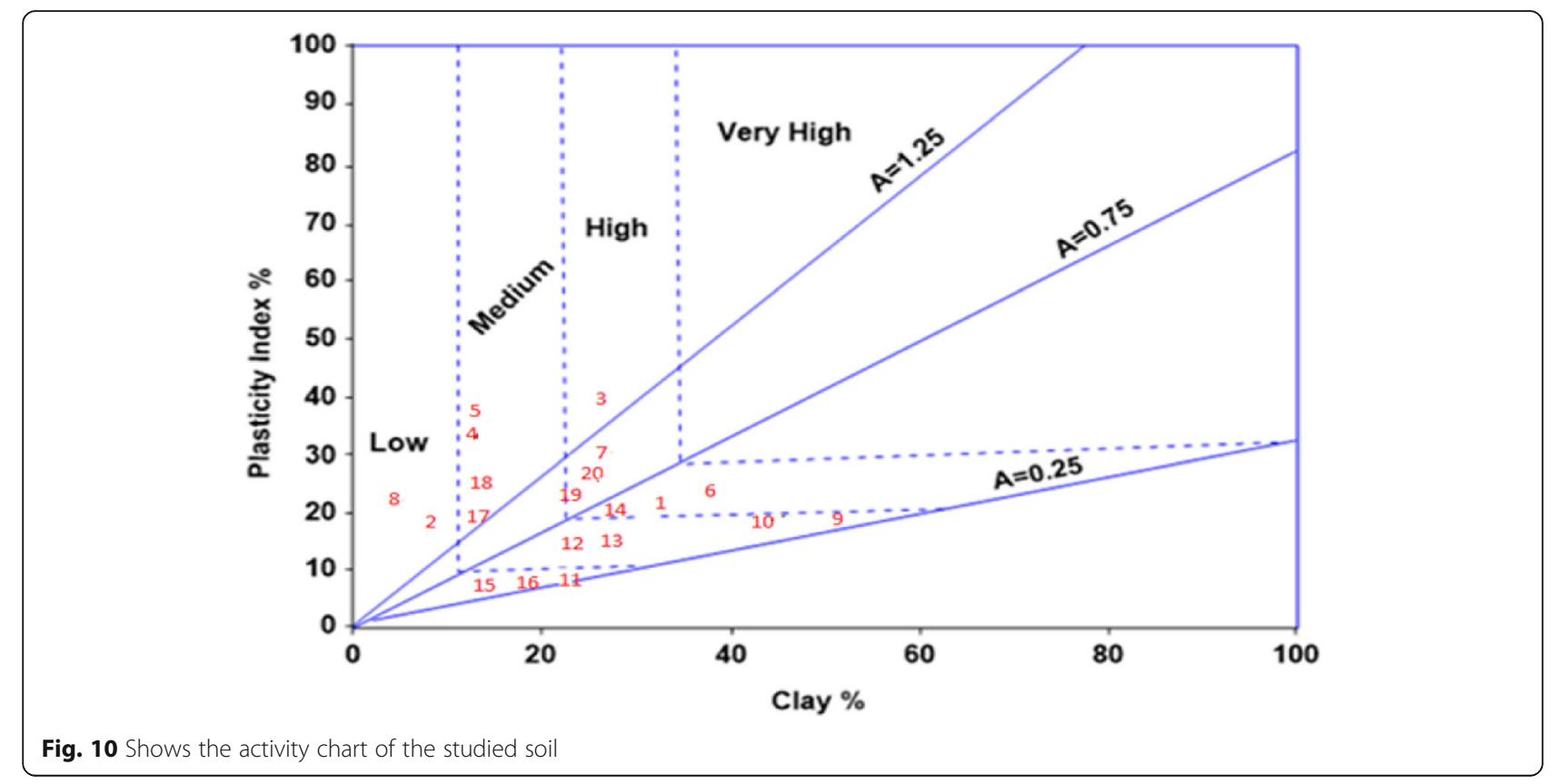


Table 7 Expansive soil classification based on shrinkage index (IS 1498 (1970))

\begin{tabular}{ll}
\hline Degree of expansivity/swell potential & Shrinkage index (\%) \\
\hline Low & $<15$ \\
Medium & $15-30$ \\
High & $30-60$ \\
Very high & $>60$ \\
\hline
\end{tabular}

above $1.70 \mathrm{~g} / \mathrm{cm}^{3}$. FMWH (1997) recommends that soils should be in the range of $1.50-1.78 \mathrm{~g} / \mathrm{m}^{3}$ for the MDD and optimum moisture content (OMC) of $8.56-12.02 \%$. The implication is that the residual soils in the studied area have low bearing capacities due to its low OMC and MDD. The soils cannot be used as construction materials except the materials are well compacted and stabilized appropriately in order for void spaces in the soil to be removed; these will intermittently reduce the permeability and increase the strength of the soil materials. It is worthy to note that for any soils to be suitable as foundation materials such soil must be compacted above the MDD and the OMC values in order for its to give rise to the required strength that will withstand the impact of load and impede the inflow of water (Olofinyo et al. 2019). The results in comparison to Underwood (1967) revealed that the studied soil samples have fair to poor foundation attribute. This comparative low maximum dry density value is potentially responsible factor to the persistence incidence of road failure in the study area.

The CBR curves for the studied soils are shown in Fig. 12. The California bearing ratio is usually used in evaluating the soils strength of subgrade, subbase and base course as road construction materials (Adeyemi 2002; Adeyemi 2013; Olofinyo et al. 2019). The CBR values for the sample locations is in the range of $3-5 \%$ for base course, $4-8 \%$ for subbase course and $3-12 \%$ for subgrade (Table 4). These results fell below the maximum of $80 \%$ recommended by the (FMWH 1997). The recommended CBR value of $>/ 5 \%$ for subgrade was met in some location. The implication of these results is that the soils are of low strength and for the strength of the soil to be increased, soil improvement methods would have to be employed before it can be used as road construction. (FMWH 1997) proposed that California Bearing Ratio (CBR) should be greater than $10 \%$ for subgrade materials. The results revealed that the CBR values of some soils are lower than the recommended value. The corresponding low values of CBR are partly responsible for the failure of highway pavement in the study area.

\section{Conclusion}

Geotechnical, mineralogical, geochemical and geophysical investigations have been carried out along SagamuPapalanto highway southwestern Nigeria. The results revealed that the soil samples are majorly granular and clayey soils, easily compacted with poor drainage. The soil samples indicate a variable moisture content due to the climatic and hydrological conditions of the area. The result of the studied soil based on AASHTO classification revealed that $20 \%$ of the soils are classified as A-2-4 whereas others outstanding $80 \%$ are classify as A-2-6, A-5 and A-7 which are reflective of fair to poor foundation attribute. However, the low specific gravity values obtained from the
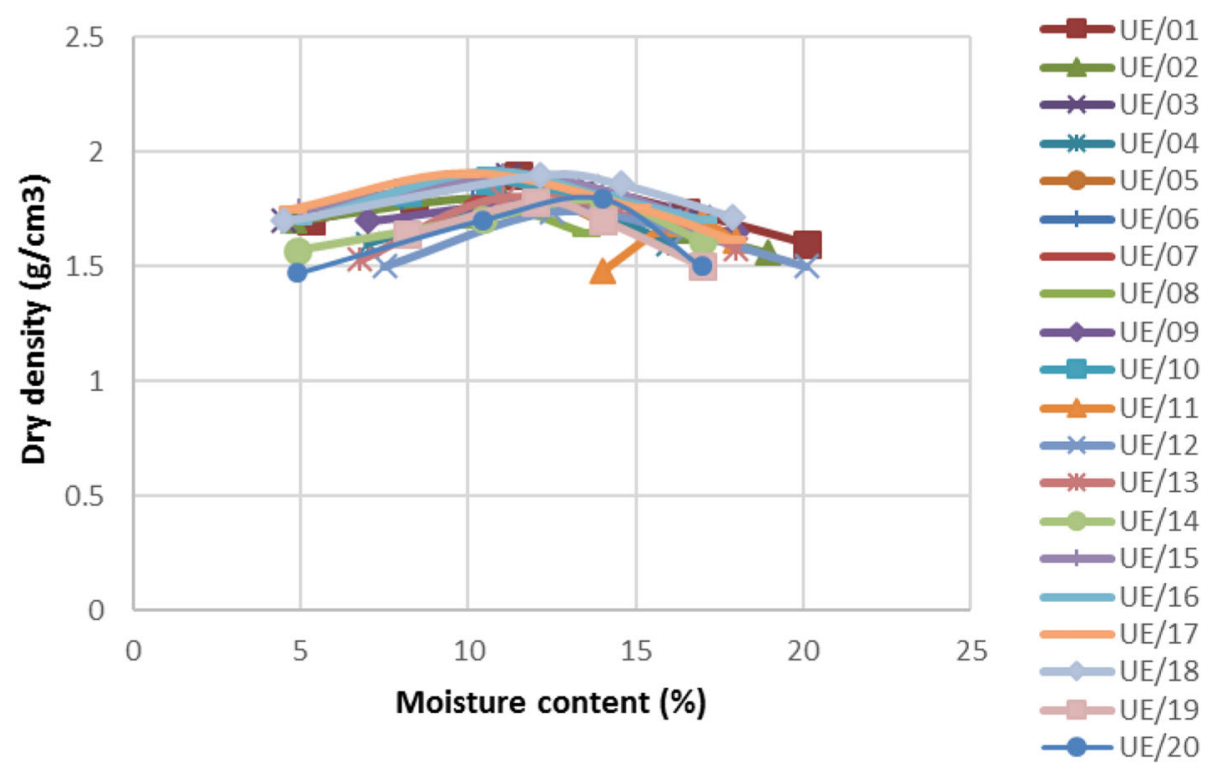

Fig. 11 Stacked compaction curves for samples UE 1-20 

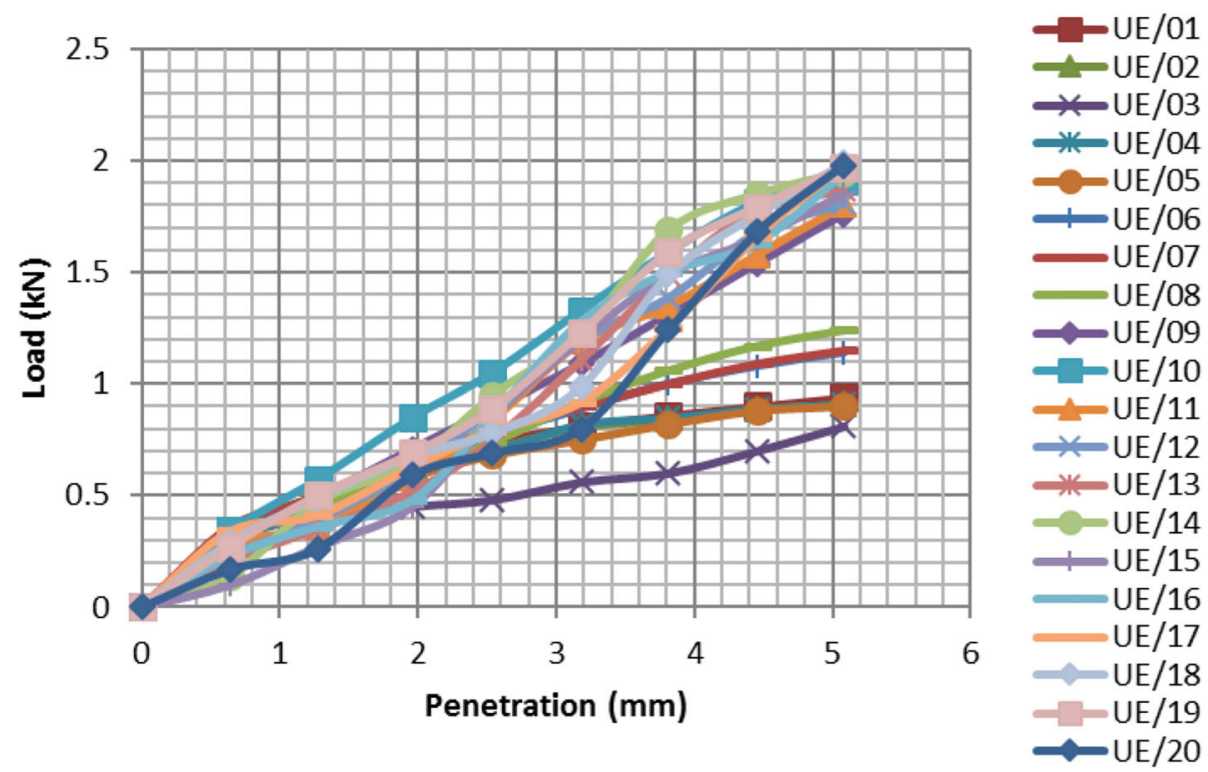

Fig. 12 Stacked CBR curves for samples UE 1-20

investigation is partly responsible for the failure of road as an increase in specific gravity values reflects a reduction in void ratio. The mineralogical investigation showed the absence of swelling clay such as montmorillonite and smectite. The minerals identified are kaolinites and illites in a major proportions and muscovite in a minor proportion. The chemical test also revealed that the soils are true laterites showing high concentration of sesquioxides $S / R$ (iron and aluminum oxides). The low CBR values obtained makes the soil materials to be unfit for use as road construction materials. Hence, their use as subgrade, subbase construction materials for heavy road traffic will require pre-treatment with non- plastic soils like bitumen, cement and lime. Low resistivity values below $200 \Omega \mathrm{m}$ were obtained in some sections of profile 2,3 and 4 . This revealed the presence of an incompetent material beneath the subsurface of the road. These materials are unfit as subgrade materials for road pavement, as it will regularly expand and contract under varying weather condition. The frequent expansion and contraction of these subgrade material often results to cracks and the eventual collapse of the road. In addition, moderately high resistivity values greater $200 \Omega \mathrm{m}$ were observed along the profile 1 shows the presence existence of laterite material which is an acceptable subgrade material for road pavement. The results of the geotechnical and geophysical investigation showed that the materials are of low shear strength but the strength can be improved when subjected to stabilization measures. This should be put into consideration during the reconstruction and rehabilitation of the exiting road. Other contributing factors such as inadequate drainage system, paucity of maintenance, poor pavement coating of the road, and substandard construction materials are factors leading to a total failure of the road. Sections of the road with sandy and clayey materials should be scooped out from the subsurface to a depth of $3 \mathrm{~m}-5 \mathrm{~m}$ from the top soil of the road and put back with competent fill materials.

\section{Acknowledgements \\ Many thanks to the editor and reviewers for their assistance in re-shaping and improving the quality of this research article.}

\section{Authors' contributions}

UOE carried out the field and Laboratory work drafted the manuscript. IO and UBU Conceived the study participated in its design, coordination and gave academic guidance. All authors read and approved the final manuscript.

\section{Funding}

Funding of the entire work was personal.

\section{Availability of data and materials}

The data sets used and analyzed during the current study are available from the corresponding author on request.

\section{Competing interests}

The authors declare that they have no competing interests.

Received: 11 July 2020 Accepted: 23 December 2020

Published online: 22 January 2021

\section{References}

AASHTO (1993) Standard specification for transportation materials and methods of sampling and testing, 14th edn. American Association of State Highway and Transportation Officials, Washington, DC

Abam TKS, Osadebe CC, Omange GN (2005) Influence of geology on pavement performance: A case study of Shagamu-Benin road. Glob J Geol Sci 3(1):17-24

Adegoke OS, Ogbe FGA, Jan Du Chene RE (1976) Excursion to the Ewekoro quarry (Paleocene-Eocene). Geol. Guide Nigerian Cretaceous-Recent Loc, pp 1-17

Ademilua O (2018) Geotechnical characterization of subgrade soils in Southwestern Part of Nigeria. In: Proceedings of first and second 
international conferences of the Nigerian Association of Engineering Geology and the Environment, Lagos, Nigeria, n.d.. vol 1, pp. 42-48.

Adeyemi GO (1995) The influence of parent rock factor on some engineering index properties of three residual lateritic soils in southwestern Nigeria. Bull Int Assoc Eng Geol 52:3-8

Adeyemi GO (2002) Geotechnical properties of lateritic soils developed over quartz schist in Ishara area southwestern Nigeria. J Mining Geol 38(1):65-69

Adeyemi GO (2013) Engineering geology: the Big Heart for structures and their environment. In: An Inaugural Lecture 2012/2013 University of Ibadan 21 February 2013. Ibadan University Press, Publishing House University of Ibadan, Ibadan, p 91

Aghamelu OP, Okogbue CO (2011) Geotechnical assessment of road failures in the Abakaliki area, southwestern Nigeria. Int J Civil Environ Eng 11(2):12-24 s

Ako BD, Adegoke OS, Peters SW (1980) Stratigraphy of Oshosun formation in Southwestern Nigeria. J Min Geo. 17:99-106

Akpan O (2005) Relationship between road pavement failures, engineering indices and underlying geology in a tropical environment. Glo J Geos 3(2): 99-108

Alexander WS, Maxwell J (1996) Controlling shrinkage cracking from expansive clay sub-grade. In: Francken LB, Molenaar AA (eds) Reflective cracking in pavements, 2nd edn. E\&FN Spon, London, pp 64-71

Altmeyer WT (1956) Discussion. Transit ASCE 121:666-669

Amadi AN, Akande WG, Okunlola IA, Jimoh MO, Francis-Deborah G (2015) Assessment of the geotechnical properties of lateritic soils in Minna, North Central Nigeria for road design and construction. Amer j Min \& Metal 3(1): 15-20 https://doi.org/10.1269/ajmm-3-1-3

Amadi AN, Eze CJ, Igwe CO, Okunlola IA, Okoye NO (2012) Architect's and Geologist's view on the causes of building failures in Nigeria. Mod Appl Sci 6(6):31-38

Arora KR (2009) Soil mechanics and foundation engineering. Standard Publishers Distributors, Delhi

ASTM D4318-10(2015) Standard Test Methods for Laboratory Consistency Limits Test.

ASTM D6913-04 (2009) Standard Test Methods for Particle Size Distribution (Gradation). ASTM International, West Conshohocken

ASTM D698-12. (2015) Standard Test Methods for Laboratory Compaction Test for Road Bases.

ASTM D854-10 (2015) Standard Test Methods for Laboratory Porosity and Permeability Test for Road Bases.

ASTM D854-14 (2015) Standard Test Methods for Specific Gravity of Soil. West Conshohocken, www.astm.org

Balogun O (2003) Senior secondary atlas. Longman, Lagos

Brink ABA, Parridge JC, Williams AAB (1982) Soil survey for engineering. Clarederon, Oxford

British Standard (BS) 1377 (1990) Methods of testing soils for civil engineering purposes. British Standards Institution, London

British Standard Institute (BSI) 5930 (1999) Code of practice for site investigation. London. p 148

Carrol D (1971) Clay minerals: a guide to their X-ray identification of soils. In: Geological society of America special paper 126, USA

Cassagrande A (1947) Classification and identification of soils. Am Soc Civil Eng. 113:783-811

Chen FH (1965) The use of piers to prevent the uplifting of lightly loaded structure founded on expansive soil. In: Concluding proceedings engineering effects of moisture change in soils, international research and engineering conference on expansive clay soils. A\&M, Texas, pp 152-171

Chen FH (1988) Foundations on expansive soils. Elsevier, Amsterdam

Daramola SO, Malomo S, Asiwaju-Bello YA (2015) Engineering geology of failed sections of Isua-Idoani road Southwestern Nigeria. J Enviro Ear Sci 5(19):38-45

Daramola SO, Malomo S, Asiwaju-Bello YA (2018) Premature failure of a major highway in Southwestern Nigeria. The case of Ipele-Isua highway. Inter J Geo-Eng 9:1-12

FMWH (1997) Nigerian general specifications for roads and bridges. Federal Highway Department. 2:145-284

Garber JN, Hoel LA (1999) Traffic and highway engineering. Brooks/Cole publishing.

Gidigasu MD (1973) Review of identification of problem laterite soils in highway engineering. Transport Res Board 497:96-11

Gidigasu MD (1976) Geotechnical evaluation of residual gravels in pavement construction. Eng Geo 15:173-794
Gidigasu MD (1983) Development of acceptance specifications for tropical gravel paving materials. Eng Geo 19:213-240

Gopal R, Rao ASR (2011) Basic and Applied Soil Mechanics, 2nd edn. New Age Int'l, New Delhi

Graham J, Shields DH (1984) Influence of geology and geological processes on the geotechnical properties of plastic clay. J Eng Geo 22(2):109-126

Gupta BL, Gupta A (2003) Roads, railways, bridges, tunnel and harbor dock engineering, 5th edn. Standard Publishers Distributors, Nai Sarak, New Delhi

Holtz WG, Gibbs HJ (1956) Engineering properties of expansive clays. Trans ASCE 121:641-663

Ighodalo CA (2009) Transport Infrastructure and Economic Growth in Nigeria. Revised Paper Submitted for Presentation at the First International Conference on Transport Infrastructure (ICTI 2008), Beijing, China. April 24-26, 2008

International Joint Committee Properties on Mineral Powder Diffraction Standard (1980) Mineral powder diffraction file data book. IJCPS, Pennsylvania

IS: 1498 (reaffirmed 1987) (1970) Indian standard classification and identification of soils for general engineering purposes. BIS, New Delhi

Jegede G (1997) Highway pavement failure induced by soil properties along the F209 highway at Omuoke, southwestern Nigeria. Nig J Sci.

Jegede G (1998) Effects of some engineering and geological factors on highway failures in parts of Southwestern Nigeria. Unpublished Ph.D. thesis. Federal University of Technology, Akure, p 251

Jegede OG (2004) Highway pavement failure induced by poor geotechnical properties at a section along the F209 Okitipupa-lgbokoda highway, Southwest Nigeria. Ife J Sci 6(1):41-44

Jegede OG, Olaleye BM (2013) Evaluation of engineering geologic and geotechnical properties of subgrade soils along re-alligned Igbara-lkogosi Highway, South-west Nigeria. Inter J Eng \&Sci 2(5):18-21

Kabir MH, Taha MR (2004) Assessment of physical properties of a granite residual soil as an isolation barrier. Elec J Geot Eng 92:13

Lambe TW (1951) Soil testing for engineers. Wiley, New York, p 165

Loughnan FC (1969) Chemical weathering of silicate minerals. Elsevier, New York

Madedor AO (1983) Pavement design guidelines and practice for different geological areas in Nigeria. In: Ola SA (ed) Tropical soils of Nigeria in engineering practices. Balkena. Publishers, Rotterdam, pp 291-298

Meshida EA (2006) Highway failure over talc-tremolite schist terrain: a case study of the Ife to llesha Highway, Southwestern Nigeria. Bull Eng Geo \& Environ 65:457-461. https://doi.org/10.1007/s10064-005-0037-7

Naresh CS, Nowatzki PE (2006) Soils and foundations. Ref Man Fed Highway Adm 2:8-75

Nwankwoala HO, Amadi AN (2013) Geotechnical investigation of sub-soil and rock characteristics in parts of Shiroro-Muya-Chanchaga Area of Niger State, Nigeria. Inter J Ear Sci\& Eng 6(1):8-17

Nwankwoala HO, Amadi AN, Ushie FA, Warmate T (2014) Determination of subsurface geotechnical properties for foundation design and construction in Akenfa Community, Bayelsa, Nigeria. Amer J Civ Eng Arch 2(4):130-135

Ogunsanwo O (1988) Basic geotechnical properties, chemistry and mineralogy of some laterite soils from southwestern Nigeria. Bul Inter Ass Eng Geo 37:131-135

Oke SA, Amadi AN, Abalaka AE, Nwosu JE, Jibade SA (2009) Index and compaction properties of laterite deposits for road construction in Minna Area, Nigeria. Nig J Cons Tech Man 10(1-2):28-35

Okogbue CO (1988) The physical and mechanical properties of laterite gravels from south eastern Nigeria relative to their engineering performance. J Afr Earth Sci 5(6):659-664

Okosun EA (1990) Review of the Cretaceous Stratigraphy of the Dahomey Embayment, West Africa. Creta Res 11:17-27

Ola SA (1983) In: Ola SA, Balkama AA (eds) Tropical soils of Nigeria in engineering practice, Netherlands, pp 61-24

Olofinyo OO, Olabode OF, Fatoyinbo IO (2019) Engineering properties of residual soils in part of Southwestern Nigeria: implication for road foundation. SN Appl Sci. 1:507. https://doi.org/10.1007/s42452-019-0515-3

Omatsola ME, Adegoke OS (1981) Tectonic Evolution of Cretaceous Stratigraphy of the Dahomey Basin. J Min \& Geo. 18(1):130-137

Onana VL, Ngooze A, MedjoEko R, Ntouala RFD, NangaBineli MT, Owoudou BN, Ekodeck GE (2017) Geological identification, geotechnical and mechanical characterization of charnokite-derived lateritic gravels from southern Cameroon for road construction purposes. Trans Geotech 10:35-46

Owoyemi OO, Adeyemi GO (2012) Highway geotechnical properties of some lateritic soils from the sedimentary terrain of Lagos-Ibadan highway. Int J Sci Eng Res 3(1):1-14 
Ramamurthy TN, Sitharam TG (2005) Geotechnical engineering. S. Chand, New Delhi, p 28

Salami BM, Falebita DE, Fatoba OJ, Ajala MO (2012) Integrated geophysical and geotechnical investigation of a bridge site-a case study of swamp/creek environment in SE Lagos, Nigeria. Ife J Sci 14(1):75-82

Skempton AW (1953) The colloidal activity of clays, Proceeding of the 3rd international conference on soil mechanics, Zurich, pp 57-5s

Snethan DR, Johnson LD, Patrick DM (1977) An evaluation ofexpedient of methodology for identification of potentiallyexpansive soils. In: Soils and Pavements Lab, US Army Eng.Water Way Exp. Station, Vicksburg, MS, Report No. FHWA-RE-77-94, NTIS PB-289-164.

Sowers GM, Sowers GE (1970) Introductory soil mechanics and foundations. Macmillan, New York, p 556

Underwood LB (1967) Classification and identification of Shales. J Soil Mech Found 93(11):97-116

\section{Publisher's Note}

Springer Nature remains neutral with regard to jurisdictional claims in published maps and institutional affiliations.

\section{Submit your manuscript to a SpringerOpen ${ }^{\circ}$ journal and benefit from:}

- Convenient online submission

- Rigorous peer review

- Open access: articles freely available online

High visibility within the field

- Retaining the copyright to your article

Submit your next manuscript at $\boldsymbol{\nabla}$ springeropen.com 